\title{
The Paradox of Representation and the Problem with Recognition: What Does it Mean to be Visible?
}

\author{
By Laura Dixon (University of Manchester) and Jennifer Tomoe Peachey (University \\ of Manchester)
}

In this edition of Anthropology Matters, contributors explore how notions of visibility are intertwined with processes of representation and recognition in social life. Furthermore, they investigate implications this intertwining has on our interlocutors and collaborators - as well as for anthropologists themselves. In particular, contributors concern themselves with the experience of, and implications arising from, persons being simultaneously 'excluded' and 'included' from and into a sociocultural framework. But why explore this dynamic in terms of vision and visibility?

Over the past few decades, there has been an increased emphasis on the sensory (for example Feld 1982; Stoller 1989; Howes 1991, 2005; Desjarlais 1992; Classen 1993, 2005; Geurts 2002). Whilst vision has played a role in this sensory turn, emphasis has tended to be on non-visual sensorality, with an overt focus on vision and visuality being couched as ocularcentric or ethnocentric. (See Fabian (1983) for the relationship between ocularcentrism and anthropology's representational practices.) In spite of these concerns, we pursue visibility in so far as people explicitly strive to make themselves visible to others. Indeed, people create themselves or aspects of themselves, as a spectacle in performances, as aesthetic objects in rituals to confirm and confer ancestral blessing, as gendered or racialised citizens or beings in political and legal contexts, and so forth.

What being visible and what the act of looking do are, of course, contestable and open to cross-cultural variation. The person or thing that is made visible to the naked eye may be neither the thing that an audience 'sees' nor the thing at stake: Morphy (1992) observes that the brilliance that one sees in Yolngu paintings is not regarded by the Yolngu as (an effect of) the painting itself, but as a manifestation of ancestral power. Again, it has been argued for various Papua New Guinean communities that concealing items, persons and knowledge from view and revealing (or eliciting) such 'things' are potent acts in social process (Gell 1975; Strathern 1988, 1992; J. Weiner 1988).

Here, however, we draw on scholars who regard endeavours to make oneself visible as an attempt to be 'recognised'. Work on recognition has been wide-ranging, from psychoanalytical approaches in which recognition is used as a 'way of representing the contingent and historically open-ended nature of...subject formation' (McNay 2008: 24. For examples see Benjamin 1998; Zizek 1989), to feminist 'narrative' approaches in which scholars seek to 'modify discourse ethics so that it encompasses a more adequate understanding of embodied social identity' (McNay 2008: 96. For examples see: Benhabib 1999; Lara 1998). Perhaps it is within political philosophy more widely, however, that concepts of recognition have been the most prominent. In this literature, scholars drew on the Hegelian dialogical subject to tie recognition to a 
concept of identity or the 'subject' as an intersubjective phenomenon. This subject provided a contrast to the normative, monological subject that predominated throughout much Western philosophy and promoted an 'inclusionary' narrative of the relation between self / other in contrast to the 'exclusionary' nature of the poststructural subject.

For example, writing from the perspective of the socially dominant, Taylor (1989, 1994) treats recognition as something that is conferred to the 'other' if that 'other' is judged to be worthy of it. Honneth (1996) regards reciprocal recognition as a prerequisite for ethical social life, noting that it is only when we are positively recognised by others that a subject gains autonomy: it is when others trust us that we come to trust ourselves. Fraser $(1997,2000)$, meanwhile, attempts to move away from a purely identity based recognition to a recognition concerned with social status. Fraser regards this latter as more explicitly related to the redistribution of wealth and power than identity. In focusing on status and redistribution, Fraser's aim is to focus on the 'concrete forms of juridical discrimination, government policy, professional practice or sedimented moral and ideological codes' that work to constitute some actors as inferior (McNay 2008:148; Fraser 1997:11-12; 2000:107; for a critique of Fraser's attempt to move away from a purely identity based recognition see Butler 1997a). Oliver (2001) has argued that underlying Hegel's, and thus the aforementioned theorists', arguments is the notion vision as a distancing sense: it is vision as a separating sense that creates and perpetuates the notion of 'self' as distant from 'other', 'subject' as distinct from 'object', a situation that she critiques as 'a pathology of oppression,

As such, recognition constitutes an intersubjective act that is at its base a negotiation of power wherein one party seeks recognition and the other confers it - a potentially, although not necessarily, reciprocal act. ${ }^{2}$ It is this attempt to render oneself visible in social or political processes according to someone else's (social, cultural, political or aesthetic) framework which simultaneously 'excludes' and 'includes' one from a socio-cultural framework. (See Fanon 1967 [1952]; Butler 1997b: 3, 10.) It is this situation that constitutes 'the paradox of representation' and 'the problem with recognition' of our concern.

\footnotetext{
${ }^{1}$ Oliver herself argues against this form of vision, drawing on Gibson (1950, 1961, 1966), Merleau-Ponty (1968), Vasseleu (1998) and Irigaray (1999) in order to do so. ${ }^{2}$ Please note the contrast with the Papua New Guinean case as analysed by Strathern (1992). In her reference to ritual performance, Strathern notes that 'looking' at a performance involves decomposing what one sees into the relations that constitute what it is that one looks upon. Crucially, this process gives those that are doing the looking, 'power as witnesses to their own efforts of elucidation [that is, their power at eliciting these relationships]' (Strathern 1992: 245, parenthesis mine). This power is indivisible but transmissible as audience and performers alternate in performing for one another. Indeed, writing of power and gender, Strathern (1988) notes that whilst equality through 'sharing' power between the sexes is impossible, either sex may evince power totally.
} 
The edition opens with a visual piece by Jessica Kendall in which photographs of performers in an 'African-themed circus' that is touring in Europe are juxtaposed with pieces of text related to their lives off-stage. Whilst the photographs capture the dynamism of the performers in action, the text invites the viewer to re-assess the images more carefully. The space 'in-between' that is opened up by such juxtaposition is intended to be a creative one. It is in this space that viewers are asked to pose their own questions and seek their own interpretations of what it is that they see.

On the one hand, perhaps this space asks the viewer to consider what identity is being constructed and represented through the performance (a 'circus performer', 'Africanness', 'Africa' itself, 'maleness' and so on). As such, Kendall may be asking the viewer to reflect upon how, and for whom, this identity is constructed. The issue that juxtaposition raises is thus of the power differential at the core of (mis)representation: the attempts of 'African' performers to express or define themselves hinges upon making themselves visible within the visual and aesthetic context of a non-indigenous circus framework for the 'European' gaze.

On the other hand, the space opened up by juxtaposing photograph and text also critiques this very critique of (mis)representation. For, however well-founded the above concern may be, is it not an assumption that the misrepresentation and misrecognition at hand is of an ethnic or national ilk - that 'Africanness' is what is at stake? Again, is it not an assumption that the problem lies in the framing of 'Africanness' through a circus aesthetic for a non-African audience? In this way, Kendall's contribution provokes us to think more carefully of how anthropologists, and academics in general, frame 'the problem of representation' itself.

In providing neither guidance nor answers in terms of how to view her work, Kendall's piece asks us to question our own assumptions of what it is that is being made visible and by whom in the context of the circus. It points us towards thinking more carefully about what vision 'is' and 'does' in academic notions of 'representation' and 'recognition'.

Bryanna Hocking's essay continues along a similar theme. Hocking explores the notion of representation through the transformation of a wall, once erected to divide Protestant and Catholic areas of Belfast (known as a 'peace wall' in the post-conflict context), into an outdoor 'art gallery'. Funded by bodies including Northern Ireland's Department of Arts, Culture and Leisure and the European Union, art on the Protestant side of the wall was meant to represent a particular, but communal, history; a history cleansed of any reference to any conflict. Behind the 'art gallery', then, lurks an assumption of how visibility represents a political identity. Specifically, the creation a visual representation of Protestant history is regarded as means of representation that enables those it depicts to be made visible and vocal: the creation of the 'art gallery' is an enabling act that restores agency.

The irony, however, is that the act of creating this visual representation re-inscribes and concretises power imbalances. Local people have little involvement in the inception and creation of the 'art gallery'. Again, the way in which local people can be represented is heavily circumscribed, with participants unable to use the one symbol that unequivocally represents them within their socio-political context: the 
Union Jack. Finally, it emerges that the aim of the wall-cum-gallery is not to represent local people to themselves, but rather to represent local people to tourists. The wall then, despite the 'art' that adorns it, remains a dividing wall and a site of contestation, leading us back to the question of what it is that is being made visible, and for whom, in processes of political representation.

If it appears that the act of making visible implies a denial of agency in the above pieces, our final Contributor, Jessica Taylor, provides a challenge to this view. Drawing on her experience as a volunteer in a community of adults with learning disabilities, Taylor suggests that observational drawing operated as a mode of communication. Indeed, drawing was something that she started to do partly in response to the requests of the women depicted in the pictures that accompany her piece.

She argued that being able to communicate with the women through drawing opened up a space in which 'rendering visible' created an arena of intersubjectivity beyond the verbally discursive. Specifically, Taylor suggests that using drawing in this context rendered representation dialogical in a way that offered a vital potential for agency in the communicative gap between speech and reciprocation that the women's disabilities rendered impossible. Taylor's argument is reflected in the dual inspiration for her piece. Her drawing on anthropology and art therapy is indicative of how the experiential and emotional dimensions of simultaneously being 'excluded' from and 'included' in modes of representation (and the assumptions these processes presuppose), can be gainfully explored through a dialogue between disciplines themselves.

\section{About the authors}

Laura and Jennifer are $\mathrm{PhD}$ candidates in Social Anthropology at the University of Manchester. Laura's research explores the negotiation of subjectivity specifically in relation to nationality and homosexuality amongst British expats living in a 'gay tourist town' in Spain. Jennifer is interested in the visiblity of emotional pain in Papua New Guinean socio-legal contexts and emotional pain as a force in social life.

\section{Bibliography}

Benhabib, Selya (1999), 'Sexual Difference and Collective Identities: The New Global Constellation', Signs: Journal of Women in Culture and Society, 24: 335-361.

Benjamin, Jessica (1998), Shadow of the Other: Intersubjectivity and Gender in Psychoanalysis, London: Routledge.

Butler, Judith (1997a), The Psychic Life of Power: Theories in Subjection, Stanford, Calif: Stanford University Press.

------ (1997b), 'Merely Cultural', Social Text 15:52/53 (Fall/Winter) 265-277.

Classen, Constance (1993), Worlds of sense : exploring the senses in history and across cultures, London [u.a.]: Routledge. (2005), The book of touch, Oxford; New York: Berg.

Desjarlais, Robert R. (1992), Body and emotion : the aesthetics of illness and 
healing in the Nepal Himalayas. Philadelphia: University of Pennsylvania Press.

Fabian, Johannes (2002), Time and the other : how anthropology makes its object, New York [u.a.]: Columbia Univ. Press.

Fanon, Frantz (1967), Black Skin, White Masks, Trans. Charles Lam Markmann, New York: Grove Press.

Feld, Steven (1990), Sound and Sentiment: Birds, Weeping, Poetics, and Song in Kaluli Expression, 2nd ed. Philadelphia: University of Pennsylvania Press.

Fraser, Nancy (1997), Justice interruptus : critical reflections on the "postsocialist" condition, New York, NY [u.a.]: Routledge.

------ (2000), 'Rethinking Recognition', New Left Review 3 (May-June): 107-120.

Gell, Alfred (1975), Metamorphosis of the Cassowaries : Umeda society, language and ritual, London [u.a.]: Athlone Pr. [u.a.].

Geurts, Kathryn Linn (2002), Culture and the senses : bodily ways of knowing in an African community, Berkeley, Calif. [u.a.]: Univ. of California Press.

Gibson, James Jerome (1961), 'Ecological Optics', Vision Research 1: 253-62.

------- (1966), The Senses Considered as Perceptual Systems, Boston: Houghton Mifflin.

------- (1974), The Perception of the Visual World, Westport, Conn: Greenwood Press.

Honneth, Axel (1996), The Struggle for Recognition, Trans. Joel Anderson. Boston: MIT Press.

Howes, David, and Marc Lalonde (1991), 'The history of sensibilities: Of the standard of taste in mid-eighteenth century England and the circulation of smells in post-revolutionary France', Dialectical Anthropology 16 (2): 125-135.

Howes, David (2005), Empire of the Senses: The Sensual Culture Reader, Oxford ; New York: Berg.

Irigaray, Luce (1999), The forgetting of air in Martin Heidegger, Trans. Mary Beth Mader, London: Athlone.

Jay, Martin (1991), 'The Disenchantment of the Eye: Surrealism and the Crisis of Ocularcentrism', Visual Anthropology Review 7 (1) (March): 15-38.

Lara, Maria Pia (1998), Moral Textures: Feminist Narratives in the Public Sphere. Cambridge: Polity Press.

McNay, Lois (2008), Against Recognition, Cambridge: Polity Press.

Merleau-Ponty, Maurice (1975), The visible and the invisible : followed by working notes, Ed. Claude Lefort. Trans. Alphonso Lingis. Evanston: Northwestern University Press.

Morphy, Howard (1992), From Dull to Brilliant: the aesthetics of spiritual power among the Yolngu, In Anthropology, Art, and Aesthetics., ed. Jeremy Coote and Anthony Shelton, 181-208, Oxford: Oxford University Press.

Oliver, Kelly (2001), Witnessing: Beyond Recognition. Minneapolis, MN: University of Minnesota Press.

Stoller, Paul (1989), The taste of ethnographic things : the senses in anthropology, Philadelphia: University of Pennsylvania Press.

Strathern, Marilyn (1988), The gender of the gift : problems with women and problems with society in Melanesia, Berkeley [u.a.]: University of California Press.

------- (1992), 'The Decomposition of an Event', Cultural Anthropology 7 (2) (May 1): 244-254.

Taylor, Charles (1989), Sources of the Self: The Making of the Modern Identity, 
Cambridge, Mass: Harvard University Press.

------- (1994). The Politics of Recognition, In Multiculturalism, ed. Amy Gutman. Princeton, N.J.: Princeton University Press.

Vasseleu, Cathryn (1998), Textures of light : vision and touch in Irigaray, Levinas and Merleau-Ponty, London [u.a.: Routledge.

Weiner, James F. (1988), The heart of the pearl shell : the mythological dimension of Foi sociality, Berkeley [u.a.]: Univ. of California Press.

Žižek, Slavoj (1989), The Sublime Object of Ideology, Phronesis. London ; New York: Verso. 